\title{
HR PRACTICES IN THE EDUCATION SECTOR (WITH SPECIAL REFERENCE TO B-SCHOOLS IN BANGALORE)
}

\author{
*Dr. ShubhaMuralidhar **Dr. R K Gopal
}

\begin{abstract}
:
The Education sector has been growing tremendously over the decade. Higher Education in India has stretched numerous folds. The number of Universities in 1947 was only around 20, but today there are a number of Universities catering different segments of teachers and students across the world. The need for Education has seen a tremendous need across the globe. Post-independence India has witnessed an above average growth in the number of Educational institutions vis-à-vis its population. With the number of colleges increasing, there is a substantial increase in the teaching staff. There are several top B schools in the city with best infrastructure; best teachers and the best students choose them because of the best placements provided to them. Inspite of this, there is a need to understand the HR practices in the education sector. This paper makes an attempt to understand the level of job satisfaction with respect to the HR practices among the teaching fraternity.
\end{abstract}

Key words: Education, HR Practices, job satisfaction, Educational Institutions

\section{Introduction:}

An academic revolution is in the process in the education sector as there is a marked change in the scope and opportunity. There is a paradigm shift in bringing about a change in this dynamic sector. In the recent years education sector has become an enterprise having a business orientation, facing fierce competition from similar groups. There is a need to bring in the right kind of people into this sector to make it more challenging. In a technology driven society, knowledge plays prime role in writing the fate of a nation and this knowledge is evident in higher education. This demands a massive investment in higher education so that highly skilled manpower can be ensured.
Higher education system in the developing country is going through a radical change in the recent times. It has laid emphasis on quality and social accountability. With the advent of globalization, achieving excellence in several areas such as student performance and competitiveness, qualification of faculty, research promotion, training and developing the right kind of staff and so on has become challenging.

\section{Review of literature:}

The last two decades has seen a substantial impact due to globalization in several areas, including the academic institutions all over the world. Higher Education institutions have been

I Author
$\begin{aligned} & \text { Dr. Shubha Muralidhar } \\ & \text { Assistant Professor } \\ & \text { Department of Management Studies and } \\ & \text { Research Centre, BMS College of Engineering, } \\ & \text { (Affiliated to VTU. Belgaum), Bangalore } \\ & \text { Email : shubha.muralidhar@gmail.com }\end{aligned}$


both the agent and objects of globalization (Scott, 1998). This suggests that there is a need for change. Successful colleges and universities are committed to finding ways to keep pace with technology change; in this regard, they recognize the growing importance of the role of human resources as an agent of continual transformation (Ulrich, 1998). A partnership between an institution's chief human resource officer (CHRO) and its chief information officer (CIO) can greatly facilitate proactive planning for and garnering of institutional, employee, and community support as well as implementing campus initiatives in response to technological change.

International mobility, global comparison, benchmarking etc. has gained lot of importance in policy making. Teichler (2004) asserts that the deliberation on global phenomena in Higher Education is focusing on marketization, competition and management. Some of the countries adopted institutional decentralization, quasi-market competition in the system and performance managed staffing to address the global competition (Valimaa, 2004). The other countries have responded differently to the changes in global environment. One of the key prerequisites is to create a large and a highly capable pool of teachers and scholars who can provide academic leadership in teaching and research. The numbers of these scholars are on the rise as there is a growing demand for the right kind of knowledge in both Indian and foreign Universities. To understand the present scenario of the Education sector, this goal of building an enhanced group of staff requires a combination of several different strategies, like,

- a change in the criteria for academic recruitment and promotion,

- $\quad$ significant improvements in the economic condition of the academic teaching profession,
- a very ambitious program for the identification, training, support and placement of young scholars, and

- a major effort at repatriating successful Indian scholars from abroad.

However, it is not easy to implement the above measures.

Literature on HRM practices reveals that HRM practices influence the organizational working both internally as well as externally. The relationship of HRM can be studied with respect to Employee-employer relationship, competitive advantage, organizational commitment, employee performance, employee productivity, financial performance, trust, effective utilisation of employees and their management, growth and innovation, job satisfaction, reduced employee turnover and improved technology. HRM is assumed to affect knowledge, skills, abilities (Schuler \& Jackson, 1995), attitudes and behaviour of employees (Guest, 1997), and may therefore affect the performance of an organisation (Den Hartog, Boselie, \& Paauwe, 2004). The alignment of HRM with the organisation strategy (strategic fit) and the alignment of the various HRM practices, such as career opportunities, training and appraisal, within the organisation (internal fit) (Baron \& Kreps, 1999) are assumed to be important factors in explaining the link between HRM and organisational performance. When HRM within an organisation is well aligned, the employees know what is expected of them, may therefore act similarly and have uniform expectations about work and behaviour (Baron \& Kreps, 1999).

Several studies have been conducted in the area of HR practices to understand its impact on organizational performance, productivity, talent management and so on. Devanna, Fombrum and Tichy (1984) in their model have depicted 
the various tasks of human resource management. Their model claims that the attempt to develop a quality culture starts with the selection of employees with the appropriate characteristics. Effective recruitment is subsequently important and specific media for advertising should be selected with a view to hiring staff. Realistic and precise job descriptions would inspire the candidates as it would help them in reflecting their true abilities in relation to the particular job. Selective methods in the organization should test applicant abilities in problem-solving and teamwork (Bowen and Lawler, 1992).

Waldman (1994) has a theory about performance focusing on staff factors such as awareness, skills, attitude, and individual motivation and also on the system factors such as work environment restrictions and requirements. Waldman argues that these factors affect one another, and together they will represent a determinant for the performance of the organization.

HRM practices can be almost everything coupled with management of employment relations within organization (Jackson \& Schuler, 1995). According to Jackson and Schuler (1995), HRM practices comprise of a system that attracts, develops, motivates, and retains employees to ensure the effective implementation and the survival of the organization and its members.

\section{Objectives:}

- To study the HR practices in the Education Sector.

- To study the impact of HR practices on Job satisfaction

- To rank the HR practices in the education sector

- To suggest suitable measures to improve the HR practices in the education sector.

\section{Scope and significance of the Study:}

The scope of this study is limited to the educational institutions offering MBA/PGDM programmes in Bangalore city. The educational institutions chosen for the study were accredited either by the NAAC or the NBA.

This research aims to understand the best HR practices prevailing in the education sector. Given the present scenarios there is need for every organization to become competent in delivering the best to both the internal as well as the external customers. Both the tangible and the intangible value created by the organization in the minds of the employees plays a dominant role in enhancing morale of individual employee and the productivity of the organization on the whole. This research will provide significant insights to benchmark HR practices in the respective industry and adopt a best HR practice by which retention of knowledgeable employees becomes effortless

\section{The key variables considered for the study}

An independent variable is one "that influences the dependent variable in either positive or a negative way" (Cavana et al., 2001, Sekaran, 1992). Dependent variables are the ones that are observed and measured in response to the independent variable. The aim of the study was to understand the HR practices in the education sector and to help the educational institutions appreciate the importance of assessing the best practices. The independent and the dependent variables are listed below:

\subsection{Independent variables:}

- Recruitment and Selection (RAS)

- Training and development (TAD)

- Compensation and fringe benefits (CFB)

- $\quad$ Performance appraisal (PA) 
- Employee wellness (EW)

- $\quad$ Career progression and retention (CPR)

- Employee engagement (EE)

- Knowledge management (KM)

- $\quad$ Entertainment at workplace. (EAW)

5.2 Dependent Variables:

- Job satisfaction (JS)

- $\quad$ Talent Management (TM)

6. Research methodology:

This study was conducted in two phases:

(a) Survey of employees in the Educational institutions which offer MBA/PGDM programs

(b) Survey of HR managers/senior managers/ administrative staff who handle the HR related activities in the educational institutions

Hence the study had a sample of 195 employees and a sample of 20 HR managers/senior managers/ administrative staff. This will enable us to find out the perception of both the management as well as the employees.

\subsection{Research Instrument for Data collection}

Structured questionnaire was used for primary data collection. Two questionnaires, one each for the Employees and HR managers' were developed. Discussions with the academicians in the concerned field and the literature survey helped in generating the potential scale of items relevant for the study. The questionnaire was discussed with the senior members of the Education sector before the pilot study. The items were evolved through exploratory study. Cronbach's Alpha reliability was done to ascertain the reliability of the questionnaire. The research attempts to measure the perception of both the employees and the HR managers to understand the best practices in each sector.

\subsection{Statistical tools used for analysis:}

Data analysis consisted of descriptive statistics such as mean, standard deviation and test of hypotheses such as correlation, analysis of variance (ANOVA). Regression analysis was further conducted to study the impact of HR practices on Job Satisfaction.

\section{Analysis and Discussions:}

Table 7.1: Demographic profile of respondents (employees)

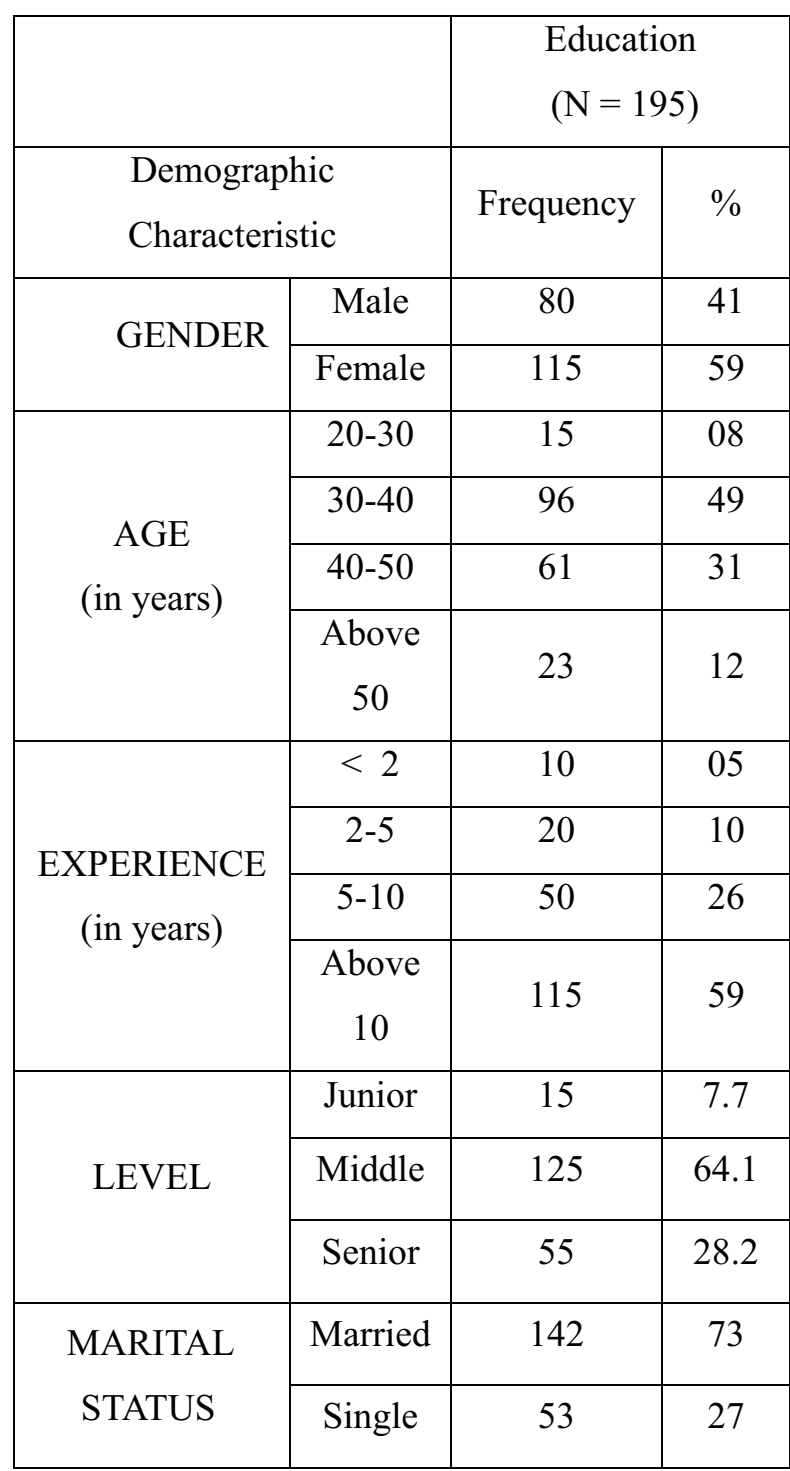


In the education sector, 195 respondents were considered from the top 10 institutions. The mix of respondents was as follows: Among 195 respondents 80 of them were male and 115 were females. The percentage of female teachers is generally more in this sector. Based on the age group, 15 respondents had less than 2 years of teaching experience, 20 between 2 to 5 years, 50 respondents between 5 years to 10 years and 115 respondents had more than 10 years. Hence the sample had employees who had more experience in this sector, thus indicating a good understanding of HR practices in the education sector. 15 respondents were from the junior level, 125 from the middle level of hierarchy and 55 respondents were from the senior level. These levels here indicate the Assistant professors, Associate professors and the Professors in various educational institutions. Among 195 respondents, 142 were married and 53 of them were single.

Table 7.2: Descriptive statistics

\begin{tabular}{|l|l|l|l|}
\hline \multirow{2}{*}{ S1.No. } & \multirow{2}{*}{ Variables } & \multicolumn{2}{|c|}{$\begin{array}{c}\text { Education } \\
\text { N=195 }\end{array}$} \\
\cline { 3 - 4 } & & Mean & $\begin{array}{l}\text { Standard } \\
\text { Deviation }\end{array}$ \\
\hline 1 & RASM & 2.95 & 0.53 \\
\hline 2 & TADM & 3.01 & 0.76 \\
\hline 3 & CFBM & 2.34 & 0.96 \\
\hline 4 & PAM & 3.10 & 0.79 \\
\hline 5 & EWM & 2.80 & 0.77 \\
\hline 6 & CPRM & 3.22 & 0.78 \\
\hline 7 & EEM & 3.62 & 0.63 \\
\hline 8 & KMM & 3.13 & 1.01 \\
\hline 9 & EAWM & 3.01 & 0.81 \\
\hline 10 & JSM & 3.31 & 0.85 \\
\hline 11 & TMM & 3.75 & 0.72 \\
\hline & & & \\
\hline
\end{tabular}

The above table indicates the descriptive statistics for all the variables across all the three sectors. The weighted average mean and the standard deviation for all the variables have been enlisted above. These results have been used in combination with other tests for analyzing the data.

\section{Table 7.3: Demographic profile of respondents (HR Managers)}

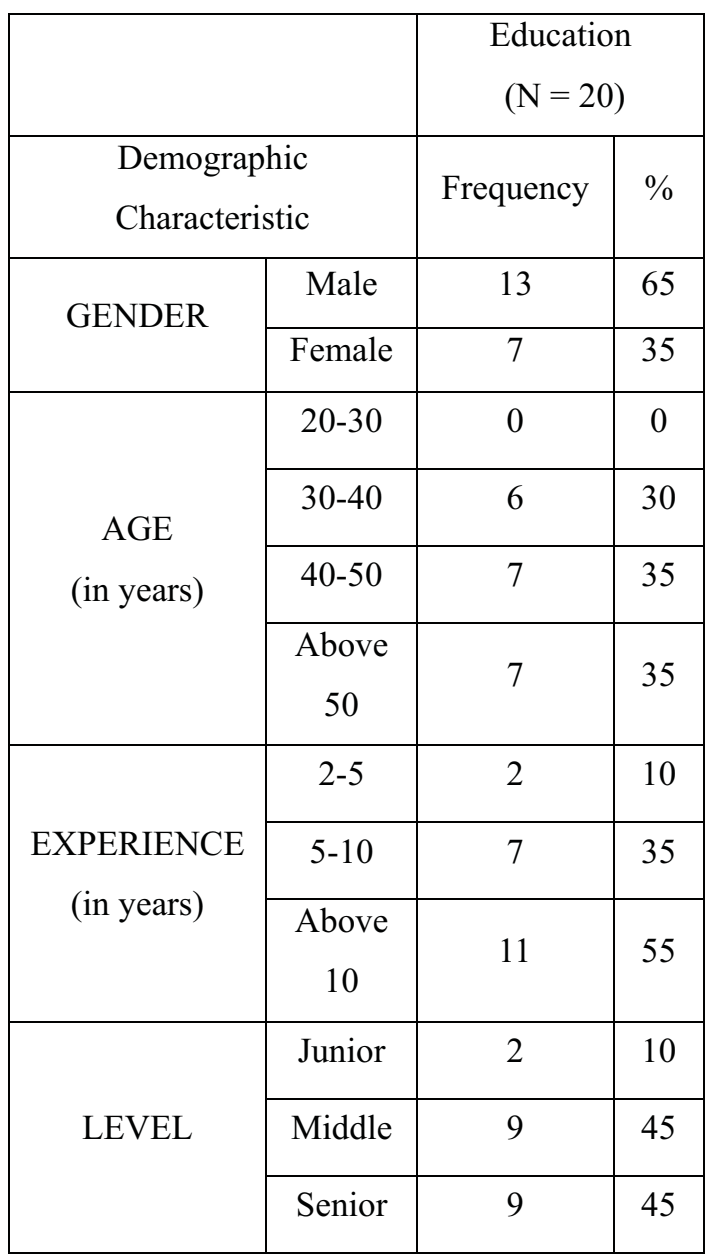

In the educational institutions, HR managers are not very commonly present. But due to the regulation of AICTE, some of them do have HR managers who take of care of all the HR activities within the institution. In some of the cases responses were elicited senior administrative staff like the Directors and Administrative officers. 13 of them were males and 7 of them were female. There were no respondents in the age group of 20-30 years, 6 in the age group of 30-40 years, 7 each in the 
age group of 30-40 years and above 50 years. 2 respondents had an experience of 2-5 years, 7 of them between 5-10 years and 11 of them more than 10 years. 2 respondents were in the junior level and 9 each from middle and the senior level.

Table 7.4: Correlation Coefficients (HR Practices- JS) in the Education Sector

\begin{tabular}{|c|c|c|c|c|c|c|c|c|c|c|c|}
\hline & & JS & RAS & TAD & CFB & PA & EW & CPR & $\mathrm{EE}$ & $\mathrm{KM}$ & EAW \\
\hline$P$ & JS & 1.00 & & & & & & & & & \\
\hline $\mathrm{E}$ & RAS & 0.42 & 1.00 & & & & & & & & \\
\hline A & TAD & 0.61 & 0.71 & 1.00 & & & & & & & \\
\hline $\mathrm{R}$ & CFB & 0.43 & 0.70 & 0.53 & 1.00 & & & & & & \\
\hline S & PA & 0.73 & 0.45 & 0.73 & 0.45 & 1.00 & & & & & \\
\hline $\mathrm{O}$ & EW & 0.56 & 0.39 & 0.53 & 0.74 & 0.63 & 1.00 & & & & \\
\hline $\mathrm{N}$ & CPR & 0.84 & 0.42 & 0.53 & 0.54 & 0.74 & 0.68 & 1.00 & & & \\
\hline & $\mathrm{EE}$ & 0.77 & 0.39 & 0.46 & 0.41 & 0.68 & 0.51 & 0.70 & 1.00 & & \\
\hline & KM & 0.72 & 0.54 & 0.71 & 0.53 & 0.64 & 0.72 & 0.71 & 0.53 & 1.00 & \\
\hline & EAW & 0.77 & 0.39 & 0.70 & 0.45 & 0.68 & 0.63 & 0.78 & 0.51 & 0.80 & 1.00 \\
\hline
\end{tabular}

Table 7.5: Model Summary - Education sector

\begin{tabular}{|l|r|r|r|r|}
\hline Model & R & R Square & R Square & $\begin{array}{c}\text { Std. Error } \\
\text { of the } \\
\text { Estimate }\end{array}$ \\
\hline 1 & .914 & .836 & .827 & .35799 \\
\hline
\end{tabular}

a Predictors: (Constant), EAW, RAS, EE, EW, PA, KM, CPR, CFB, TAD

Table 7.6: ANOVA results - Education sector

\begin{tabular}{|c|c|c|c|c|c|c|}
\hline \multicolumn{2}{|c|}{ Model } & $\begin{array}{l}\text { Sum of } \\
\text { Squares }\end{array}$ & $\mathrm{df}$ & $\begin{array}{l}\text { Mean } \\
\text { Square }\end{array}$ & $\mathrm{F}$ & Sig. \\
\hline \multirow[t]{3}{*}{1} & Regression & 117.870 & 9 & 13.097 & 102.192 & $.000(a)$ \\
\hline & Residual & 23.197 & 181 & .128 & & \\
\hline & Total & 141.067 & 190 & & & \\
\hline
\end{tabular}

a Predictors: (Constant), EAW,RAS,EE,EW,PA,KM,CPR,CFB,TAD

b Dependent Variable: JS 
Results: The hypothesis is accepted as the value of $\mathrm{r} 2$ is 0.836 , indicating that the model is highly significant in the education sector

Discussion: Table 7.4 shows the correlation between JS and other HR practices in the education sector. The $\mathrm{r}$ values imply that there is positive correlation among all the practices, that is the association between JS and other HR practices have a positive relationship. ' $r$ ' value is maximum between JS and CPR and the least between JS and RAS. Both individual and the organization are responsible for shaping the career. It is employees who must take keen interest in deciding their career path and the organization must support the employees in this endeavour. As the employees move up in their career, the retention index increases for the organization thus enhancing JS. Attrition rate in the education sector is increasing with number of institutes increasing. The pay scales in the Education sector are adhered only by few premier institutes and not all of them. This is major concern for attrition in most of the institutes. RAS practice is still followed in conservative approach without much innovation in its performance. The results of correlation in Table 7.4 indicate that good HR practices certainly influence job satisfaction in the educational institutions.

The HR practices RAS, TAD, CFB, PA, EW, CPR, EE and KM in the above model revealed the ability to predict job satisfaction. In this model the value of $\mathrm{R} 2=0.836$, the observed value of JS can be explained by the above given $9 \mathrm{HR}$ practices. $83.6 \%$ of the variability can be explained by the HR practices and the remaining $16.4 \%$ variability is due to other variables. The variance as per Table 4.53 is also significant ( $\mathrm{p}$-value $=0.00$ ).

The relationship between the dependent variable JS and the independent 9 practices is given in the regression equation.

Table 7.7: Regression Coefficients - Education Sector

\begin{tabular}{|c|c|c|c|c|c|c|}
\hline \multirow{2}{*}{ Model } & & \multicolumn{2}{|c|}{$\begin{array}{c}\text { Un standardized } \\
\text { Coefficients }\end{array}$} & $\begin{array}{c}\text { Standardized } \\
\text { Coefficients }\end{array}$ & t & Sig. \\
\hline & & B & $\begin{array}{c}\text { Std. } \\
\text { Error }\end{array}$ & Beta & B & Std. Error \\
\hline 1 & (Constant) & -.174 & .247 & & -.701 & .484 \\
\hline & RAS & -.204 & .103 & -.129 & -1.988 & $\mathbf{. 0 4 8}^{*}$ \\
\hline & TAD & .103 & .081 & .092 & 1.268 & $.206^{\mathrm{NS}}$ \\
\hline & CFB & .086 & .062 & .097 & 1.396 & $.165^{\mathrm{NS}}$ \\
\hline & PA & .070 & .069 & .066 & 1.022 & $.308^{\mathrm{NS}}$ \\
\hline & EW & -.312 & .081 & -.281 & -3.867 & $\mathbf{. 0 0 0 *}$ \\
\hline & CPR & .432 & .075 & .398 & 5.792 & $\mathbf{. 0 0 0}^{*}$ \\
\hline & EE & .456 & .064 & .335 & 7.101 & $\mathbf{. 0 0 0} *$ \\
\hline & KM & .199 & .057 & .235 & 3.497 & $\mathbf{. 0 0 1 *}$ \\
\hline
\end{tabular}

a Dependent Variable: JS * Highly Significant, NS not significant 
Fig 7.1: Regression model with significant practices in the Education Sector

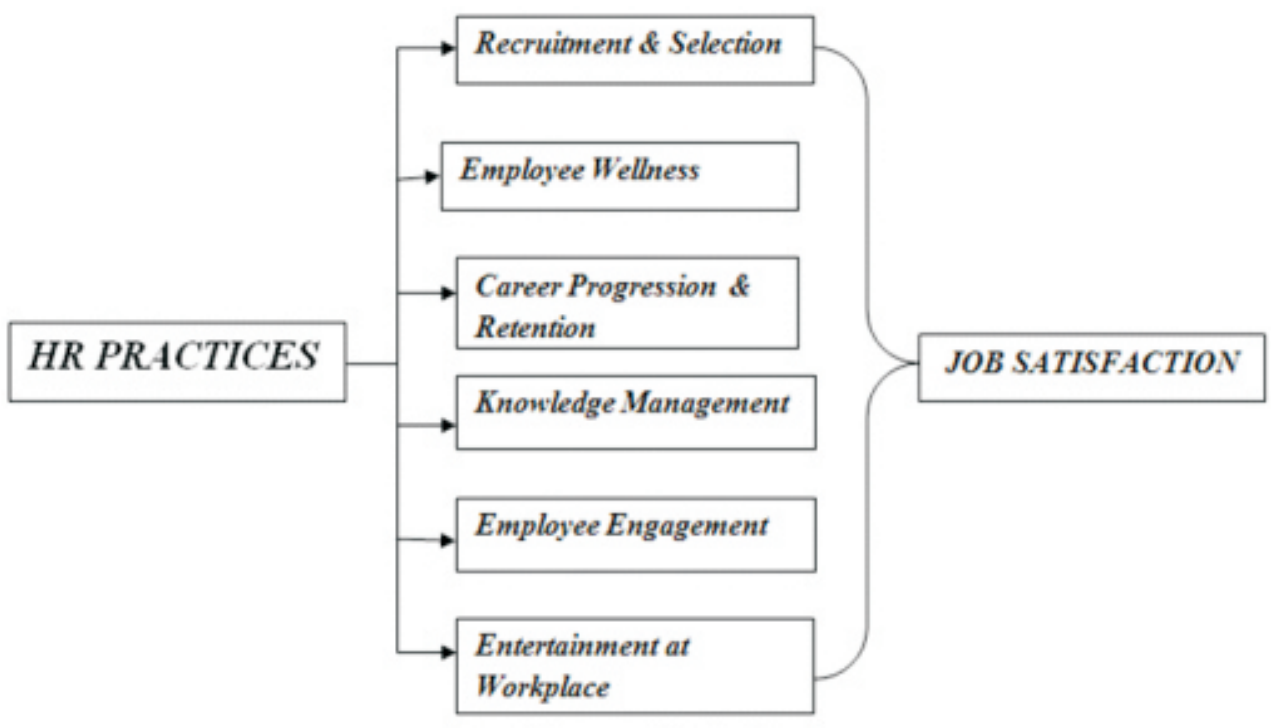

The impact of HR practices on job satisfaction in the Education sector is summarised in the equation above. The equation above implies that few HR practices have a positive impact on JS, whereas few other practices move in the negative direction. CPR, EE, KM and EAW have a positive impact, RAS and EW have a negative impact and the other practices have no significant impact on JS.

Career growth is considered to have maximum priority in the above study. Career development objectives must be aligned with the personal goals and the corporate objectives. The career path is institutionalized in an educational set up, because it is framed through the apex bodies. The employees are aware of their promotional path and they know that only by improving their qualification and their aptitude towards research they can grow. Retention of employees is possible when they attain the right qualification at the right time. Hence from the study it can be inferred that the impact of CPR on JS is in the positive direction.

Employee engagement is high in this sector due the involvement of the faculty with the other stakeholders. They have to satisfy the students, management, parents and corporate, thus making their role quite complex. The discussions with the faculty members revealed that they were passionate about teaching and felt they were engaged employees. Hence from the analysis it can be opined that there is a significant impact of EE on JS. Knowledge management is a core area in the field of education as the entire show depends on the level of knowledge the employees possess. This justifies the positive impact of KM on JS.

Training and development is an area which is a trust area in the education sector. The composite mean value of TAD among employees is 3.01 and among the administrative staff or the HR managers is 3.02. Both the values are at the neutral point. The significance of TAD is greater than 0.1 and hence the impact of increased training and development may not lead to better job satisfaction. Increasing training programmes only for numbers will not lead to job satisfaction. The employees in the education sector feel that the training should be given with a proper objective. Training and development programs must be done based on 
the requirements of the faculty members and must be useful in their class room activities. Hence in the above analysis it can be inferred that by merely increasing $T \& D$ activities, it may not lead to JS, but on the contrary reduce JS.

This implies that the other HR practices such as RAS, EW, CPR, EE and KM have a higher impact on altering the JS. RAS and EW have negative values, which indicate even if these practices are improved to a superior level, they may not show a significant impact on job satisfaction. Hence the above model summary implies that better HR practices will lead to enhanced job satisfaction.

\section{Ranking of HR practices in the education sector:}

Table 8.1: Rankinge of HR practices in the Education Sector

\begin{tabular}{|c|c|c|}
\hline Dimension & Mean & Rank \\
\hline \multicolumn{3}{|c|}{ Independent variables } \\
\hline RAS & 2.96 & 7 \\
\hline TAD & 3.02 & 5 \\
\hline CFB & 2.35 & 9 \\
\hline PA & 3.10 & 4 \\
\hline EW & 2.81 & 8 \\
\hline CPR & 3.25 & 2 \\
\hline EE & 3.62 & 1 \\
\hline KM & 3.14 & 3 \\
\hline EAW & 3.01 & 6 \\
\hline \multicolumn{3}{|c|}{ Dependent variables } \\
\hline JS & 3.31 & 2 \\
\hline TM & 3.75 & 1 \\
\hline
\end{tabular}

Employee Engagement allows an employee to understand the needs of the organization. Teaching and learning are two important aspects of the Education sector. A good mix of both the above components will make a teacher more effective thus enhancing the engagement level. According to the table, TM has a higher ranking, indicating that talented employees feel that they are valued and the work they do is of strategic importance to the Institution.

The study indicates that the employees have a fairly good connect with the Institutions, but they feel they are underpaid. Typically when Employee Engagement is discussed, it is thought that salary and perks play an important role in enhancing a teacher's individual engagement level. But the present research indicates salary is the last component which would probably lead to employee engagement. The salary structure in Education sector does not give scope for a variety of fringe benefits like the IT sector. The regular components of salary are addressed to at different hierarchical levels. Only at the strategic level, few benefits apart from the salary are specified.

The overall mean values in the Education sector are clustered around 3 and less than 3 indicating a neutral opinion of the employees with respect to all the HR practices. There is a lot of scope to bring in changes in the HR practices in the Education sector.

\section{Suggestions for practice in the Education sector}

The education sector has been conservative in its HR practices. E-recruiting strategies can be adopted as it saves time and money. The selection process in the colleges is mostly on the basis of educational qualifications and the grades. Of late most of the colleges ask for a demonstration class from the prospective 
candidate which is similar to the job knowledge test. Psychometric tests are a part and parcel of the IT sector, but do not find a place in the educational institutions. Psychometric test must be adopted to find the right personnel. Bureaucratization makes it difficult to bring about appropriate and immediate changes whenever it is required because of the changing needs of the society.

Majority of the Faculty lack appropriate training in teaching methodology. They learn as they engage themselves in teaching. Appropriate certifications for teaching must be designed to meet these training needs. Maximizing teacher competency is the first priority for any educational institution. Regular in-service training for teachers is essential through the entire span of their career. Educational institutions must give due importance to staff training and retraining needs. Teacher training must be re-examined in the context of constantly changing needs, both with respect to basic skills and for future employment imperatives. Competency mapping must be developed to have the right competencies on the job which eases the RAS process. TNA must be given priority in the education sector. TNA must be covered under three important aspects, namely, job requirements, specific needs of the individual and also the organizations need.

An institution which is focussed on research will require different competencies when compared to an institution which is focussed on teaching and is student centric. There is strong need to bring in as many of the faculty members pursue research, certification programs and other relevant courses. Few of these certifications/training programmes are very expensive and it is important for the institutions to support the employees.
It is essential to formulate a procedure for a systematic on boarding process as it would ease out the process of inducting the new employee into the organization. Employees, who are newly inducted irrespective of their age and experience, must be put through the onboarding process. This would assist the employee to easily acquaint themselves easily to the organizational systems and procedures.

Supervision, mentoring and counselling are generally discussed at length but not adequately practiced in the education sector. This becomes vital when new employees join. The senior faculty must involve themselves in the mentoring process so as to create a good institutional climate.

Knowledge in the education sector is more through the research process. The conferences and seminars conducted by each institution is an indication of this practice. Moreover most of institutions have enough funding from the AICTE, UGC, TEQIP and RUSA for knowledge sharing activities. But it is for the institutions utilize these opportunities for their advantage.

An active HR department is essential to attend to the regular needs of the employees. Most of the institutions have an administrative department which is solely responsible for administration activities. The HR needs of the employees must be addressed by a separate team of experts. When educational institutions align themselves with strategic HRM practices, they motivate the employees; enable them to deliver effective work outputs which in return result in employee retention. Similarly there is need for a specific marketing department to ensure the right kind of branding.

Social networking must be optimally used to connect with experts in their areas. The 
benefits of technology must be used to the advantage of both the students and the faculty members.

It was understood that the teaching fraternity wanted the industry-institution cells to be more active. The industry-institution interaction must boost so as to bridge the gap. The involvement of the industry nominees is essential to prepare the students adequately with requisite knowledge. The interviews with the faculty further revealed that there are more customary activities like the notes preparation, conducting of test, quiz, evaluation etc., took a substantial amount of their time which reduced the time for active research.

Teaching faculty must be deputed to industries to understand the task of design, development, various processes, etc, so that they can bring live projects to the institutions for the benefit of the students and the faculty. The higher education institutions are generally change resistant which need a thorough change in their mindsets. To remain viable and competitive, an educational institution must create and maintain academic excellence and administrative systems that keep pace with the technological change, most importantly align with the mission, vision and key intuitional goals and objectives.

Conclusion: The standards of academic recruitment have been arbitrary; the remuneration of teaching in higher education has been rather dull when compared to the private sector or the opportunities abroad. The graduate, post graduate programs and the research programs must have more academic rigour and financial support must be extended wherever possible. Adequate staffing is the critical bottleneck in India's plans for achieving academic excellence and expansion. To deal with, it will require a concentrated effort involving a change in the academic culture, improved economic conditions and ensuring that bright Indian scholars are retained to enhance research and development.

\section{References:}

- Abdul Rau of Quraishi, U. \& Kalim R. (2007), "Development of a Faculty Satisfaction Model for Higher Education", CIE Conference, Alexandria, Egypt available at: http://www.cie37.net, retrieved on 14/6/ 2008.

- Agrawal, Swati (2010), "Talent Model for business schools: A factor analysis" Indian Journal of Industrial Relations, Volume 45

- Baron, J. N., \& Kreps, D. M. (1999). Strategic human resources. Framework for general managers. New York: Wiley and sons.

- Bogan, C.E. and English, M.J. (1994), Benchmarking for Best Practices, McGrawHill, New York, NY.

- Bowen, D. E. and Lawler, E. E. 1992. "The Empowerment of Service Workers: What, Why, How, and When." Sloan Management Review, 33: 31-39.

- Cappelli, P. (2008b) "Talent Management for the Twenty-First Century." Harvard Business Review March: 74-81.

- Cavana R Y., Delahaye, B. L., \&Sekeran U.,(2001), Applied Business Research: Qualitative and Quantitative Methods, John Wiley \& Sons, Australia

- Cornesky, R. (1991), Implementing Total Quality Management in Higher Education, Magnar Publications and Madison, WI. 
- Deanne N. den Hartog, Paul Boselie and Jaap Paauwe, (2004), Performance Management: A Model and Research Agenda, Applied Psychology: An International Review, 53(4), 556-569

- Devanna, M.A., Fombrun, C.J., Tichy, N.M. (1984) 'A Framework for strategic human resource management', in Fombrun, C.J Tichy, M. M. and Devanna, M.A. (eds) Strategic Human Resource Management, New York: John Wiley

- Guest, D. E. (1997). Human Resource Management and Performance: A Review and Research Agenda. International Journal of Human Resource Management, 8(3), 263-276.

- Schuler, R. S., \& Jackson, S. E. (1995). 'Understanding human resource management in the context of organizations and their environment', Annual Review of Psychology, 46, 237264.

- Teichler, U. (2004), .The Changing Debate on Internationalization of Higher Education., Higher Education, Vol. 48, pp. $5-26$.

- Valimaa, J. (2004a), .Nationalisation, Localization and Globalization in Finnish Higher Education., Higher Education, Vol. 48 , pp. 27-54.

- Waldman, D., (1994) The contributions of TQM to a theory of work performance, Academy of Management Review, 19 (3), 501-536. 